ARGONNE IATIONAL LABORATORY 9700 South Cass Avenue Argonne, Rlinois 60439

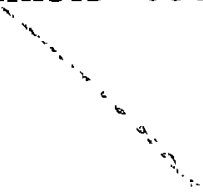

\title{
CALCULATIONAL ANALYSIS OF TESTS OF EBR-II CAPTURE-TO-FISSION RATIOS
}

by

D. Meneghetti and R. H. Rempert

EBR-II Project

NOTICE

This report was prepared as an account of work sponsored by the United States Government. Neither the United States nor the United States Atomic Energy the United States nor the United States Atomic Energy
Commission, nor any of their employees, nor any of their contractors, subcontractors, or their employees, makes any warranty, express or implied, or assumes any legal liability or responsibility for the accuracy, completeness or usefulness of any information, apparatus, pleteness or usefulness of any information, apparatus,
product or process disclosed, or represents that its use product or process disclosed, or represents
would not infringe privately owned rights.

July 1972 
$\underline{\text { Page }}$

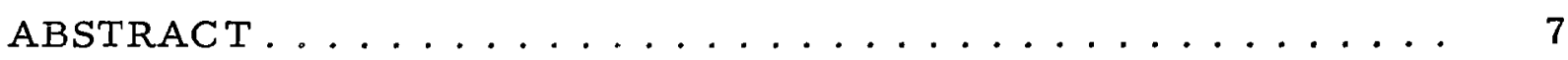

I. INTRODUCTION. ........................

II. TEST-SAMPI.E LOCATIONS AND CORE-LOADING

VARIATIONS ........................ 8

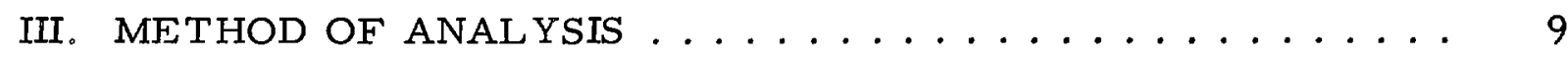

IV. RANGE OF NEUTRON-FLUX SPECTRA. . . . . . . . . . 12

V. RESULTS AND DISCUSSION .................. 12

A. Sensitivity of $\alpha$ to Variations in Core Loadings ....... 12

B. Radial Dependence of $\alpha$ Assuming RZ Geometry. . . . . 15

C. Axial Dependence of $\alpha \ldots \ldots \ldots 15$

D. Central Capture and Fission Ratios ............. 18

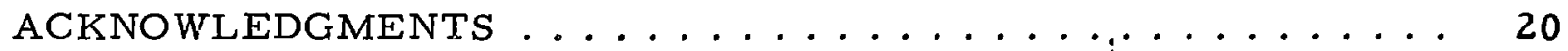

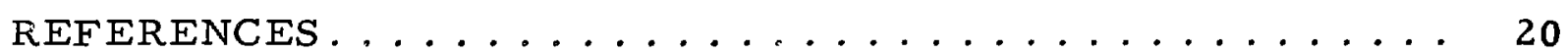




\section{LIST OF FIGURES}

No.

Title

Page

1. Distribution of Test Foils in EBR-II during Runs 5-23 .... 8

2. Extremes in Loading Variations in Sector $B$ during Foil Irradiations . . . . . . . . . . . . . . . . 8

3. XY-geometry Composite of Runs 7 and 14:

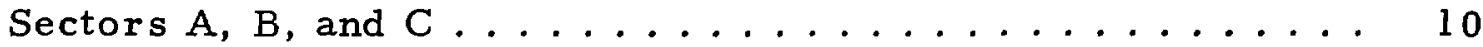

4. XY-geometry Composite of Runs 17 and 20:

Sectors A, B, and C ..................... 10

5. Major Regions Used in RZ-geometry Analysis .......... 11

6. Calculated Range of Neutron Spectra during Foil

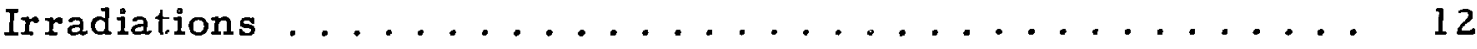

7. Values of $\alpha$ for ${ }^{235} \mathrm{U},{ }^{239} \mathrm{Pu}$, and ${ }^{233} \mathrm{U}$ in Subassemblies at Various Radial Positions in EBR-II. . . . . . . . . 15

8. Radial Profile of $\alpha$ for ${ }^{240} \mathrm{Pu}$ in EBR-II . . . . . . . . . . 15

9. Radial Profile of $\alpha$ for ${ }^{242} \mathrm{Pu}$ in EBR-II . . . . . . . . . . 15

10. Radial Profile of $\alpha$ for ${ }^{238} \mathrm{U}$ in EBR-II ............. 16

11. Radial Profile of $\alpha$ for ${ }^{233} \mathrm{U}$ in EBR-II . . . . . . . . . . 16

12. Radial Profile of $\alpha$ for ${ }^{235} \mathrm{U}$ in EBR-II . . . . . . . . . . 16

13. Radial Profile of $\alpha$ for ${ }^{239} \mathrm{Pu}$ in EBR-II . . . . . . . . . . 17

14. Axial Profile of $\alpha$ for ${ }^{240} \mathrm{Pu}$ in EBR-II . . . . . . . . . 17

15. Axial Profile of $\alpha$ for ${ }^{242} \mathrm{Pu}$ in EBR-II . . . . . . . . . . 17

16. Axial Profile of $\alpha$ for ${ }^{238} \mathrm{U}$ in EBR-II. ............. 18

17. Axial Profile of $\alpha$ for ${ }^{233} \mathrm{U}$ in EBR-II. ............. 18

18. Axial Profile of $\alpha$ for ${ }^{235} \mathrm{U}$ in EBR-II. . . . . . . . . . . 19

19. Axial Profile of $\alpha$ for ${ }^{239} \mathrm{Pu}$ in EBR-II. . . . . . . . . . . 19 


\section{LIST OF TABLES}

No.

Title

Page

I. EBR-II Run Numbers and Grid Positions for Foil

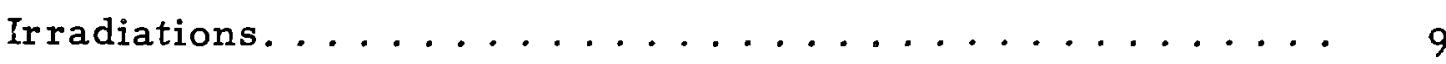

II. Approximate Compositions of Major Regions in

RZ-geometry Analysis ................... 11

III. Sensitivity of $\alpha$ for ${ }^{240}$, $u$ to Variations in Core Loading . . . 13

IV. Sensitivity of $\alpha$ for ${ }^{242} \mathrm{Pu}$ to Variations in Core Loading. . . . . 13

V. Sensitivity of $\alpha$ for ${ }^{238} \mathrm{U}$ to Variations in Core Loading . . . . 13

VI. Sensitivity of $\alpha$ for ${ }^{239} \mathrm{Pu}$ to Variations in Core Loading . . . . 13

VII. Sensitivity of $\alpha$ for ${ }^{233} \mathrm{U}$ to Variations in Core Loading . . . . 14

VIII. Sensitivity of $\alpha$ for ${ }^{235} \mathrm{U}$ to Variations in Core Loading . . . . 14

IX. Central Capture and Fission Ratios in EBR-II Core . . . . . 19 


\title{
CALCULATIONAL ANALYSIS OF TESTS OF EBR-II CAPTURE-TO-FISSION RATIOS
}

by

D. Meneghetti and R. H. Rempert

\begin{abstract}
Values of neutron flux determined by two-dimensional RZ- and XY-geometry calculations using multigroup analyses were used to obtain capture-to-fission ratios of fissile and fertile isotcpes at various radial and axial positions in a number of EBR-II core loadings. Details of geometry and loadings are considered, and the calculated ratios are compared with reported ratios obtained by foil irradiations.
\end{abstract}

\section{INTRODUCTION}

During EBR-II runs 5-23, ${ }^{1}$ fissile and fertile foils were irrradiated at various radial and axial positions in the core, radial blanket, and axial blanket of the reactor. The fission rates and the capture rates were meas ured to obtain the values of the capture-to-fission ratios $(\alpha)$ of the isotopes. The foils were ${ }^{233} \mathrm{U},{ }^{235} \mathrm{U}{ }^{238} \mathrm{U},{ }^{239} \mathrm{Pu},{ }^{240} \mathrm{Pu}$, and ${ }^{242} \mathrm{Pu}$. The experimental method and the resulting test data have been reported by $R$. $R$.. Heinrich et al. ${ }^{2}$ The calculated ratios are reported here and compared with the measured ratios.

Because of the differing compositions of subassemblies and of the loading changes, the use of an operating fast-neutron powe $r$ reactor such as EBR-II as a vehicle for obtaining reaction-rate data requires considerations of the detailed loading patterns. Since EBR-II at present functions as a fast-fuel and structural-material irradiation facility, neither the subassemblies nor the radial peripheral outline of the core-blanket interface remains the same. Analysis of axial distributions of reaction rates requires consideration of the effects of fuel-pin tops, gaps, axial blankets, and upper-fixture regions of subassemblies in the calculational model.

The calculated ratios were compared with the measured ratios in order to improve the understanding of the effectiveness of the calculational methods as well as to determine deviation trends. This study is part of the more general effort to improve understanding c.f the irradiation environment in EBR-II through foil irradiations and analytical correlations. 


\section{TEST-SAMPLE LOCATIONS AND CORE-LOADING VARIATIONS}

Figure 1 shows the approximate radial and axial positions of the test foils during runs 5-23. Not all isotope species were placed at all the posi-

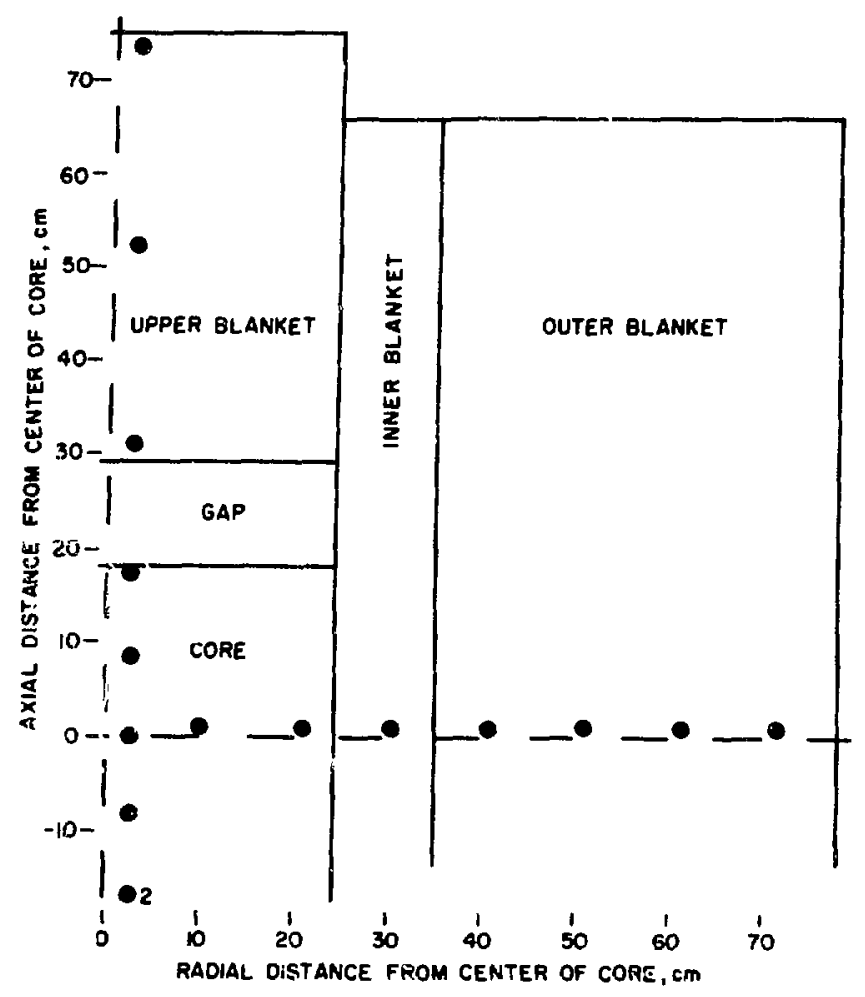

Fig. 1. $\Gamma$ 'stribution of Test Foils in I R-II during Runs 5-23 tions, nor were all foil positions occupied throughout all the runs.

Although an attempt was made to minimize loading changes during the irradiations in Sector $B$ (the radial sector in which the foils were placed), some changes were inevitable. The four loadings shown in Fig. 2 illustrate the extremes of the variations in loading in that sector during the irradiations. In the loadings for runs 7 and 17, two driver subassemblies protrude into the radial-blanket region; in the loadings for runs 14 and 20 , three driver subassemblies protrude into that region.

Foils were placed along the radial midline of Sector $B$ in subassemblies in rows $1,3,7,9,11$, 13 , and 15. A foil-containing subassembly was also in row 5, but

not along the midline of Sector B. Initially, it was in the subassembly position to the left of control rod C-10. It was subsequently transferred,

Fig. 2

Extremes in Loading Variations in Sector $B$ during Foil Irradiations ANL Neg. No. 104-296 Rev. 1.
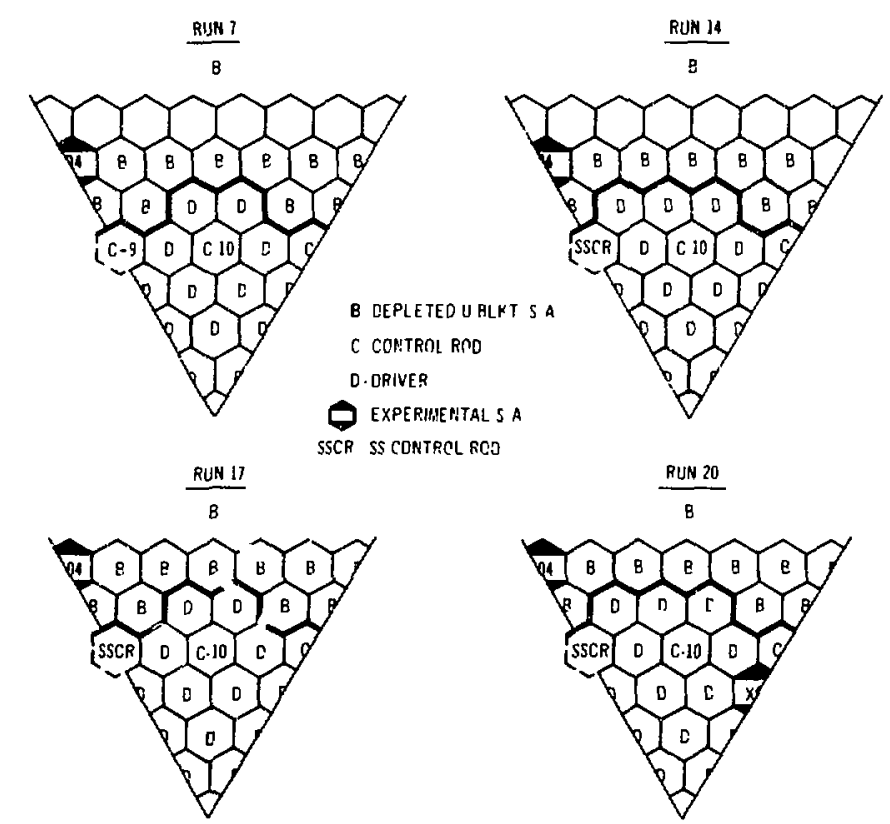
however, to the subassembly position to the right of control rod C-10. The foils in this subassembly, therefore, were adjacent to driver subassemblies, blanket subassemblies, and the stainless steel control rod (SSCR) at one time or another during their irradiation.

Table I lists the EBR-II run numbers during which the foil-containing subassemblies in the various positions were irradiated.

TABLE I. EBR-II Run Numbers and Grid Positions for Foil Irradiations

\begin{tabular}{cc|cc}
\hline Run No. & Position $^{b}$ & Run No. & Position $^{b}$ \\
\hline $7-14$ & lA1 & $5-20$ & $9 B 5$ \\
$7-14$ & $3 B 2$ & $5-20$ & $11 B 6$ \\
$9-13$ & $5 B 27 c$ & $5-23$ & $13 B 7$ \\
$14-17$ & $5 B 4\}$ & $5-23$ & $15 B 8$ \\
$5-9$ & $7 B 4$ & & \\
\hline
\end{tabular}

a Detailed information on core loadings for these runs is given in Ref. 1 .

bNumber before letter (the sector) is the row number.

cSame subassembly.

\section{METHOD OF ANAL YSIS}

The radial distributions of the capture-to-fission ratios of the irradiated fissile and fertile samples were calculated from the values of neutron flux obtained with the $\mathrm{S}_{4}$ approximation of the two-dimensional, $\mathrm{XY}$-geometry DOT transport code. ${ }^{3}$ Each hexagonal subassembly was represented by a rectangle of equivalent cross-sectional a rea and containing four mesh points. An axial buckling value of $0.0024 \mathrm{~cm}^{-2}$ was assumed in all core and blanket regions. This study used a 29-energygroup cross-section set based upon the ENDF/B (Version I) data compilation, energy-collapsed by the $\mathrm{MC}^{2}$ code ${ }^{4}$ specifically for core, gap, and blanket regions of an EBR-II type system. Energy groups 1-25 were half-lethargy widths; groups 26-29 were full-lethargy widths.

Although the irradiations encompassed many core loadings, the four loadings in Fig. 2 illustrate the extremes of the variations insofar as the tests were concerned. To estimate the effects of these loadings with minimal computer usage, two $X Y$ calculations representing composites of runs 7 and 14 and of runs 17 and 20 were made. Figures 3 and 4 , respectively, show the location of the core and nearby blanket subassemblies in 


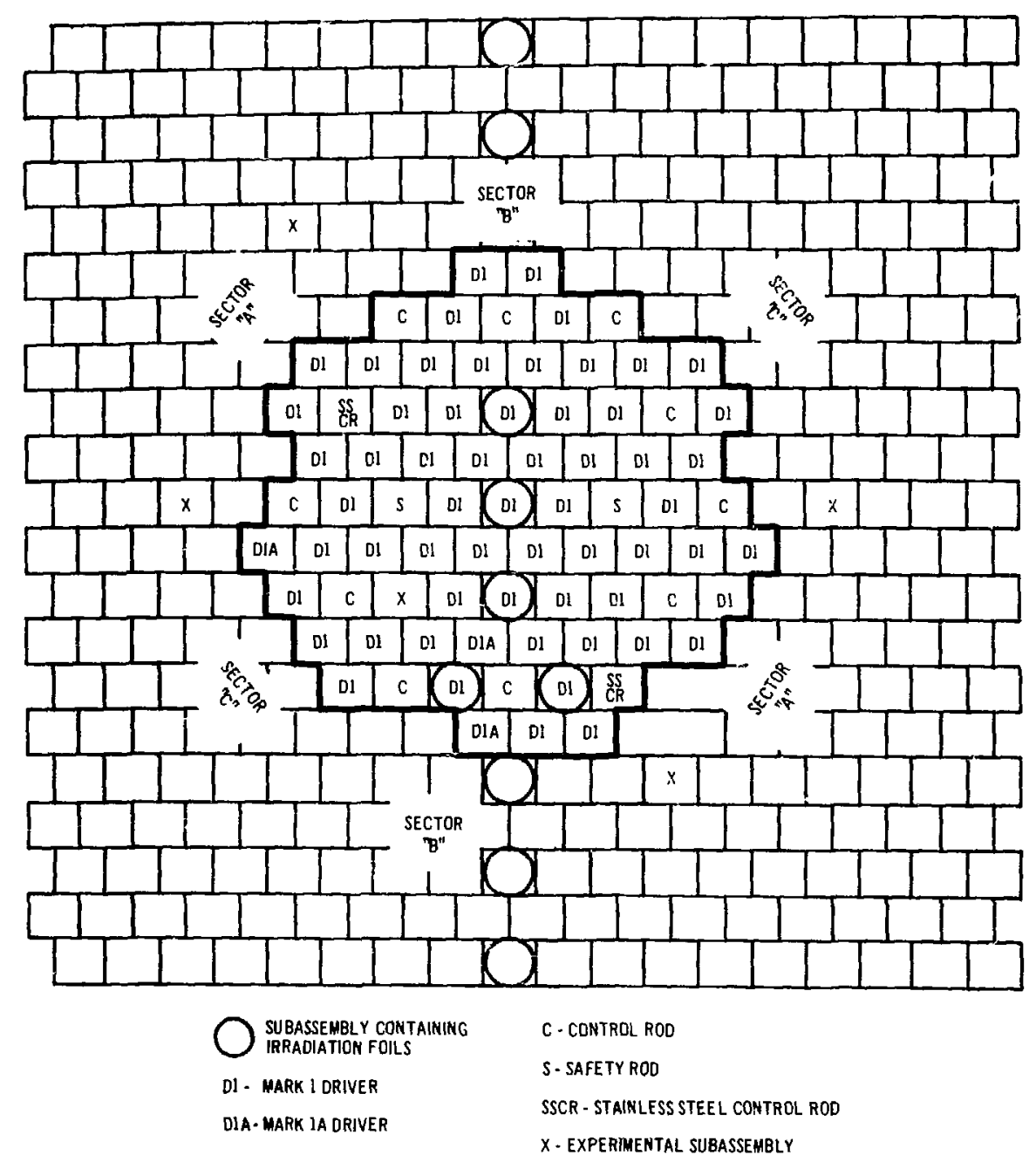

Fig. 3. XY-geometry Composite of Runs 7 and 14: Sectors A, B, and C. Run 7 - top half of diagram; run 14 - bottom half of diagram.

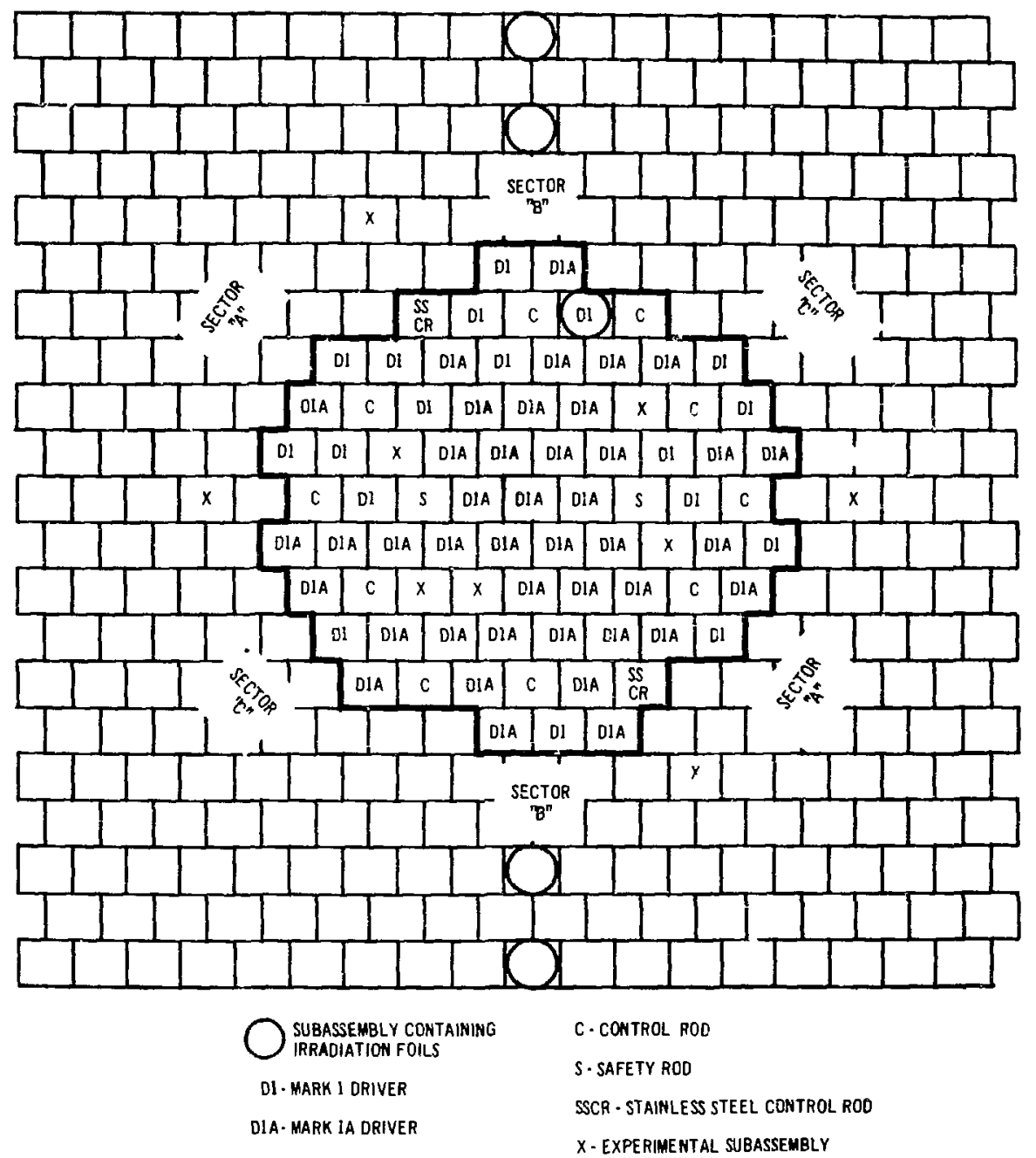

Fig. 4. XY-geometry Composite of Runs 17 and 20: Sectors A, B, and C. Run 17 - top half of diagram; run 20 - bottom half of diagram. 
these composites. Additional rows of radial blanket subassemblies, not shown in the figures, surrounded the cores. As loaded, the Mark I drivers

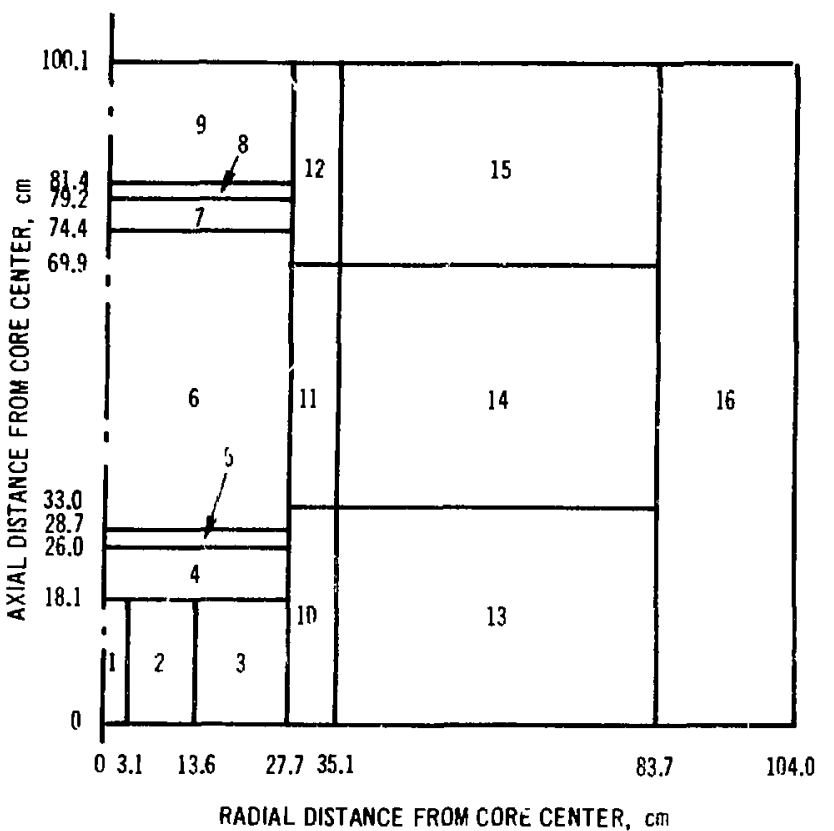

Fig. 5. Major Regions Used in RZ-geometry Analysis. (Approximate regional compositions are given in Table II.) had a ${ }^{235} \mathrm{U}$ enrichment of 48.4 at. \%, and the Mark IA drivers 52.5 at. \%.

The data for axial distribution of capture-to-fission ratios were analyzed with DOT twodimensional, RZ-geometry transport calculations in the $\mathrm{S}_{4}$ approximation. Figure 5 and Table II delineate the main radial regions and approximate compositions used in the analysis. (The actual analysis consisted of more details than shown and described here.) The radial region surrounding the central subassembly (Region 2) was chosen to be characteristic in compositions and axial details to the nearest two subassembly rows ( 2 and 3) surrounding the central subassembly during the runs in

TABLE II. Approximate Compositions of Major Regions in RZ-geometry Analysis

\begin{tabular}{clccccc}
\hline \multirow{2}{*}{$\begin{array}{c}\text { Region } \\
\text { No. }\end{array}$} & \multicolumn{2}{c}{ Region Description } & \multicolumn{4}{c}{ Composition, $10^{24}$ atoms $/ \mathrm{cm}^{3}$} \\
\cline { 3 - 7 } & & ${ }^{235} \mathrm{U}$ & ${ }^{238} \mathrm{U}$ & ${ }^{239} \mathrm{Pu}$ & Sodium & $\mathrm{SS}^{\mathrm{b}}$ \\
\hline 1 & Row 1 & 0.00615 & 0.00656 & $1.6 \times 10^{-6}$ & 0.0108 & 0.0169 \\
2 & Rows 2, 3 & 0.00620 & 0.00660 & $6.9 \times 10^{-6}$ & 0.0111 & 0.0169 \\
3 & Rows 4, 5, 6 (part) & 0.00602 & 0.00641 & $6.9 \times 10^{-6}$ & 0.0113 & 0.0169 \\
4 & Pin tops & - & - & - & 0.011 & 0.030 \\
5 & Sodium gap and grid & - & - & - & 0.011 & 0.045 \\
6 & Top axial blanket & $3 \times 10^{-5}$ & 0.013 & $\mathrm{c}$ & 0.011 & 0.018 \\
7 & Spring & - & - & - & 0.011 & 0.021 \\
8 & Half plate & - & - & - & 0.008 & 0.057 \\
9 & Upper fixture and sodium gap & - & - & - & 0.019 & 0.013 \\
10 & Radial blanket & $6 \times 10^{-5}$ & 0.029 & $2 \times 10^{-5}$ & 0.0045 & 0.017 \\
11 & Radial blanket & $6 \times 10^{-5}$ & 0.029 & - & 0.0045 & 0.017 \\
12 & Radial upper region & - & - & - & 0.018 & 0.016 \\
13 & Radial blanket & $6 \times 10^{-5}$ & 0.029 & $\mathrm{~d}$ & 0.0043 & 0.018 \\
14 & Radial blanket & $6 \times 10^{-5}$ & 0.029 & - & 0.0043 & 0.018 \\
15 & Radial upper region & - & - & - & 0.018 & 0.016 \\
16 & Radial outer region & - & - & - & 0.022 & - \\
\hline
\end{tabular}

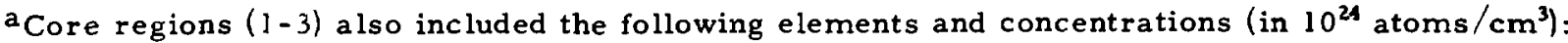
Mo, 0.00093; Nb, $0.000024 ; \mathrm{Zr}, 0.00076$.

${ }^{b}$ Composition of SS $=\sim 70$ at. $\% \mathrm{Fe}, 10$ at. $\% \mathrm{Ni}, 20$ at. $\% \mathrm{Cr}$.

${ }^{c_{\text {Axial }}}$ variation of ${ }^{239} \mathrm{Pu}$ in blanket assumed to range from $\sim 1 \times 10^{-6}$ to $7 \times 10^{-6}$ in units of $10^{24}$ atoms $/ \mathrm{cm}^{3}$.

$\mathrm{d}_{\text {Radial variation of }}{ }^{239} \mathrm{Pu}$ in blanket assumed to range from $\sim 3 \times 10^{-6}$ to $17 \times 10^{-6}$ in units of $10^{24}$ atoms $/ \mathrm{cm}^{3}$. 
which the axial foils were irradiated (runs 7-14). The composition of the outer radial region of the core (Region 3) was chosen to represent a homogenization of the core subassemblies characteristic of the outer core regions of the loadings in Sector B during those runs (5-9) in which foils were exposed in blanket positions near the core. This cylindrical annular region comprised all of rows 4 and 5 and three-fifths of row 6 . (On the average, about three-fifths of the subassemblies in row $b$ of Sector B were fueled subassemblies, and two-fifths were blanket subassemblies.) The RZgeometry calculation also provided additional radial capture-to-fission ratios, particularly for the radial regions deep into the radial blanket where the XY-geometry calculation could not give reliable values for spectra.

\section{RANGE OF NEUTRON-FLUX SPECTRA}

Figure 6 shows the range of neutron-flux spectra obtained from the RZ-geometry calculation. Both plots have been area-normalized to unity. The peak of the distribution

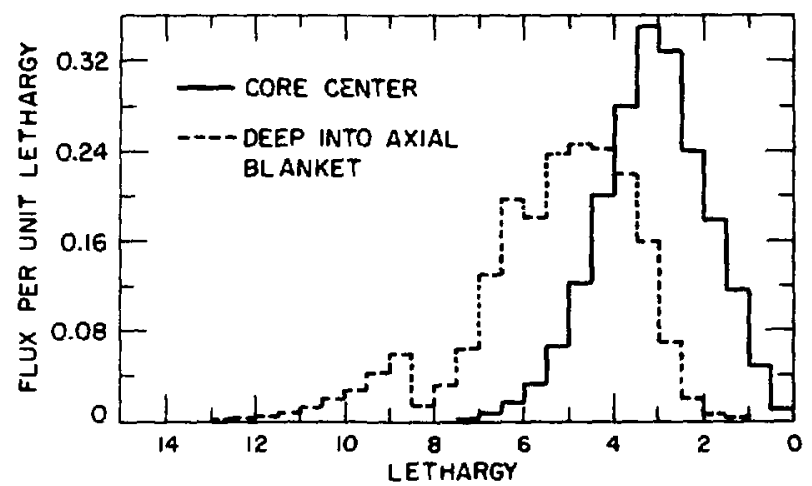

Fig. 6. Calculated Range of Neutron Spectra during Foil Irradiations. ANL Neg. No. 104-295. is at about $300 \mathrm{keV}$ for the core center and about $67 \mathrm{keV}$ deep into the top axial blanket.

\section{RESULTS AND DISCUSSION}

\section{A. Sensitivity of $\alpha$ to Variations in Core Loadings}

Table III shows the effects of variations in EBR-II core loadings on the value of $\alpha$ of the fertile is otope ${ }^{240} \mathrm{Pu}$. (The values are based on the XY-geometry analyses.) The calculated values may be compared with the reported experimental values listed in the last column. In this table, as well as in Tables IV-VIII, the calculated values for rows 1-7 are reported under the types of "extreme" loadings (runs 7, 14, 17, and 20) the foils experienced in the listed position. For example, the foils in rows 1 and 3 experienced extreme loadings like those of runs 7 and 14 during their irradiation, and the foils in row 5 experienced extreme loadings like those of runs 14 and 17 . Table III shows that the central spectrum was essentially the same for runs 7 and 14, because the value of $\alpha$ in position lAl is the same for both runs - 0.28. This compares with an experimental value of 0.30 . In the blanket, at row 9, the calculated values for $\alpha$ range from 1.05 to 1.13 , as compared with an experimental value of 1.37 . 
TABLE III. Sensitivity of $\alpha$ for ${ }^{240} \mathrm{Pu}$ to Variations in Core Loading

\begin{tabular}{|c|c|c|c|c|c|c|}
\hline \multirow[b]{2}{*}{ Position No. } & \multirow{2}{*}{$\begin{array}{c}\text { Distance from } \\
\text { Core Center, } \mathrm{cm}\end{array}$} & \multicolumn{4}{|c|}{$\begin{array}{l}\text { Calculated for } \\
\text { EBR-II Run No. }\end{array}$} & \multirow{2}{*}{$\begin{array}{c}\text { Experimental } \\
\text { (Ref. 2) }\end{array}$} \\
\hline & & 7 & 14 & 17 & 20 & \\
\hline$|A|$ & 2.9 & 0.277 & 0.277 & - & - & $0.3046 \pm 0.0094$ \\
\hline $3 \mathrm{~B} 2$ & 10.2 & 0.280 & 0.280 & - & - & $0.3078 \pm 0.0095$ \\
\hline $5 \mathrm{~B} 2$ & 21.3 & - & 0.317 & - & - & \\
\hline $5 \mathrm{~B} 4$ & 21.3 & - & 0.318 & 0.313 & - & $0.3517 \pm 0.0108$ \\
\hline $7 \mathrm{~B} 4$ & 30.6 & 0.571 & - & - & - & $0.5944 \pm 0.0183$ \\
\hline $9 B 5$ & 40.8 & 1.13 & 1.07 & 1.12 & 1.05 & $1.369 \pm 0.042$ \\
\hline $11 \mathrm{~B} 6$ & 51.0 & 1.58 & 1.53 & 1.56 & 1.51 & - \\
\hline
\end{tabular}

TABILE IV. Sensitivity of $\alpha$ for ${ }^{242} \mathrm{Pu}$ to Variations in Core Loading

\begin{tabular}{|c|c|c|c|c|c|c|}
\hline \multirow[b]{2}{*}{ Position No. } & \multirow{2}{*}{$\begin{array}{l}\text { Distance from } \\
\text { Core Center, crn }\end{array}$} & \multicolumn{4}{|c|}{$\begin{array}{l}\text { Calculated for } \\
\text { EBR-II Run No. }\end{array}$} & \multirow{2}{*}{$\begin{array}{l}\text { Experimental } \\
\text { (Ref. 2) }\end{array}$} \\
\hline & & 7 & 14 & 17 & 20 & \\
\hline$|A|$ & 2.9 & 0.208 & 0.208 & - & - & $0.4689 \pm 0.0193$ \\
\hline $3 \mathrm{~B} 2$ & 10.2 & 0.211 & 0.211 & - & - & $0.4789 \pm 0.0428$ \\
\hline $5 \mathrm{B2}$ & 21.3 & - & 0.244 & - & - & \\
\hline $5 B 4$ & 21.3 & - & 0.245 & 0.241 & - & $0.5727 \pm 0.0513$ \\
\hline $7 \mathrm{~B} 4$ & 30.6 & 0.494 & - & - & - & $1.439 \pm 0.191$ \\
\hline $9 B 5$ & 40.8 & 1.16 & 1.07 & 1.14 & 1.05 & - \\
\hline $11 \mathrm{~B} 6$ & 51.0 & 1.79 & 1.71 & 1.76 & 1.68 & - \\
\hline
\end{tabular}

TABLE V. Sensitivity of $\alpha$ for ${ }^{238} \mathrm{U}$ to Variations in Core Loading

\begin{tabular}{|c|c|c|c|c|c|c|}
\hline \multirow[b]{2}{*}{ Position No. } & \multirow{2}{*}{$\begin{array}{l}\text { Distance from } \\
\text { Core Center, cm }\end{array}$} & \multicolumn{4}{|c|}{$\begin{array}{l}\text { Calculated for } \\
\text { EBR-II Run No. }\end{array}$} & \multirow{2}{*}{$\begin{array}{c}\text { Experimenta) } \\
\text { (Ref. 2) }\end{array}$} \\
\hline & & 7 & 14 & 17 & 20 & \\
\hline$|A|$ & 2.9 & 1.65 & 1.65 & - & - & . \\
\hline $3 \mathrm{~B} 2$ & 10.2 & 1.66 & 1.67 & - & - & - \\
\hline $5 \mathrm{B2}$ & 21.3 & - & 1.93 & - & - & - \\
\hline $5 B 4$ & 21.3 & - & 1.95 & 1.90 & - & - \\
\hline $7 \mathrm{~B} 4$ & 30.6 & 4.85 & - & - & - & - \\
\hline $9 B 5$ & 40.8 & 19.7 & 17.6 & 19.0 & 16.9 & - \\
\hline 1186 & 51.0 & 46.2 & 43.2 & 45.0 & 41.5 & $33.81 \pm 1.15$ \\
\hline
\end{tabular}

TABLE VI. Sengitivity of $\alpha$ for ${ }^{239} \mathrm{Pu}$ to Variations in Core Loading

\begin{tabular}{|c|c|c|c|c|c|c|}
\hline \multirow[b]{2}{*}{ Position No. } & \multirow{2}{*}{$\begin{array}{l}\text { Distance from } \\
\text { Core Center, cm }\end{array}$} & \multicolumn{4}{|c|}{$\begin{array}{l}\text { Calculated for } \\
\text { EBR-II Run No. }\end{array}$} & \multirow{2}{*}{$\begin{array}{c}\text { Experimental } \\
\text { (Ref. 2) }\end{array}$} \\
\hline & & 7 & 14 & 17 & 20 & \\
\hline$|A|$ & 2.9 & 0.080 & 0.080 & - & - & $0.085 \pm 0.0026$ \\
\hline $3 B 2$ & 10.2 & 0.081 & 0.081 & - & - & $0.088 \pm 0.0025$ \\
\hline $5 \mathrm{B2}$ & 21.3 & - & 0.089 & - & - & $00984+00030$ \\
\hline $5 B 4$ & 21.3 & - & 0.088 & 0.087 & - & $0.0984 \pm 0.0030$ \\
\hline $7 B 4$ & 30.6 & 0.119 & - & - & - & $0.1340 \pm 0.0044$ \\
\hline $9 B 5$ & 40.8 & 0.155 & 0.151 & 0.154 & 0.150 & $0.1431 \pm 0.0044$ \\
\hline $11 \mathrm{~B} 6$ & 51.0 & 0.174 & 0.172 & 0.173 & 0.171 & $0.1845 \pm 0.0057$ \\
\hline
\end{tabular}


TABLE VII. Sensitivity of $\alpha$ for ${ }^{233} \mathrm{U}$ to Variations in Core Loading

\begin{tabular}{|c|c|c|c|c|c|c|}
\hline \multirow[b]{2}{*}{ Position No. } & \multirow{2}{*}{$\begin{array}{l}\text { Distance from } \\
\text { Core Center, } \mathrm{cm}\end{array}$} & \multicolumn{4}{|c|}{$\begin{array}{l}\text { Calculated for } \\
\text { EBR-II Run No. }\end{array}$} & \multirow{2}{*}{$\begin{array}{l}\text { Experimental } \\
\text { (Ref. 2) }\end{array}$} \\
\hline & & 7 & 14 & 17 & 20 & \\
\hline lAl & 2.9 & 0.069 & 0.064 & - & - & $0.0728 \pm 0.0022$ \\
\hline $3 \mathrm{B2}$ & 10.2 & 0.069 & 0.069 & - & - & - \\
\hline $5 B 2$ & 21.3 & - & 0.072 & 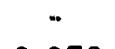 & - & $0.0713 \pm 0.0022$ \\
\hline 5B4 & 21.3 & - & 0.072 & 0.072 & - & $0.0112+0.00<2$ \\
\hline $7 \mathrm{~B} 4$ & 30.6 & 0.084 & - & - & - & 5 \\
\hline $9 \mathrm{~B} 5$ & 40.8 & 0.094 & 0.093 & 0.095 & 0.093 & $0.0950 \pm 0.0029$ \\
\hline $11 \mathrm{~B} 6$ & 51.0 & 0.098 & 0.098 & 0.098 & 0.098 & - \\
\hline
\end{tabular}

TABLE VIII. Sensitivity of $\alpha$ for ${ }^{235} \mathrm{U}$ to Variations in Core Loading

\begin{tabular}{|c|c|c|c|c|c|c|}
\hline \multirow[b]{2}{*}{ Position No. } & \multirow{2}{*}{$\begin{array}{l}\text { Distance from } \\
\text { Core Center, cm }\end{array}$} & \multicolumn{4}{|c|}{$\begin{array}{l}\text { Calculated for } \\
\text { EBR-II Run No. }\end{array}$} & \multirow{2}{*}{$\begin{array}{l}\text { Experimental } \\
\text { (Ref. 2) }\end{array}$} \\
\hline & & 7 & 14 & 17 & 20 & \\
\hline lAl & 2.9 & 0.161 & 0.161 & - & - & $0.1795 \pm 0.0055$ \\
\hline $3 \mathbf{B 2}$ & 10.2 & 0.162 & 0.163 & - & - & $0.1828 \pm 0.0056$ \\
\hline $5 \mathrm{~B} 2$ & 21.3 & - & 0.173 & - & - & - \\
\hline $5 B 4$ & 21.3 & - & 0.173 & 0.172 & - & - \\
\hline $7 \mathrm{~B} 4$ & 30.6 & 0.210 & - & - & - & $0.2299 \pm 0.0071$ \\
\hline $9 \mathrm{~B} 5$ & 40.8 & 0.247 & 0.244 & 0.247 & 0.242 & - \\
\hline 1186 & 51.0 & 0.261 & 0.262 & 0.264 & 0.261 & $0.2906 \pm 0.0089$ \\
\hline
\end{tabular}

Table IV shows the analogous values for ${ }^{242} \mathrm{Pu}$. The experimental values of $\alpha$ are more than double the calculated values. Similar results have been noted in the $\mathrm{RZ}$-geometry calculations, both radially and axially. Whether this may be a systematic error in calculation or in the experimentally obtained capture or fission rates is discussed in Sec. V.D.

Table $V$ shows the variations of the values of $\alpha$ for ${ }^{238} \mathrm{U}$. Only one experimental value - for $51 \mathrm{~cm}$ from core center - is available for comparison with calculated values. At that position, in the radial blanket, the calculated values for $\alpha$ range from 41.5 to 46.2 , as compared with an experimental value of 33.8 .

Interfacing and loading variations have considerably less effect on the $\alpha$ of fissile isotopes, largely because these isotopes do not have a threshold for fissions. Tables VI-VIII show the calculated and experimental values of $\alpha$ for ${ }^{239} \mathrm{Pu},{ }^{233} \mathrm{U}$, and ${ }^{235} \mathrm{U}$. Figure 7 plots the calculated and experimental values.

The experimental and calculated values of $\alpha$ for ${ }^{233} \mathrm{U}$ and ${ }^{239} \mathrm{Pu}$ correlate satisfactorily. The calculated values of $\alpha$ for ${ }^{235} \mathrm{U}$, however, are approximately $10 \%$ lower than the experimental values. 


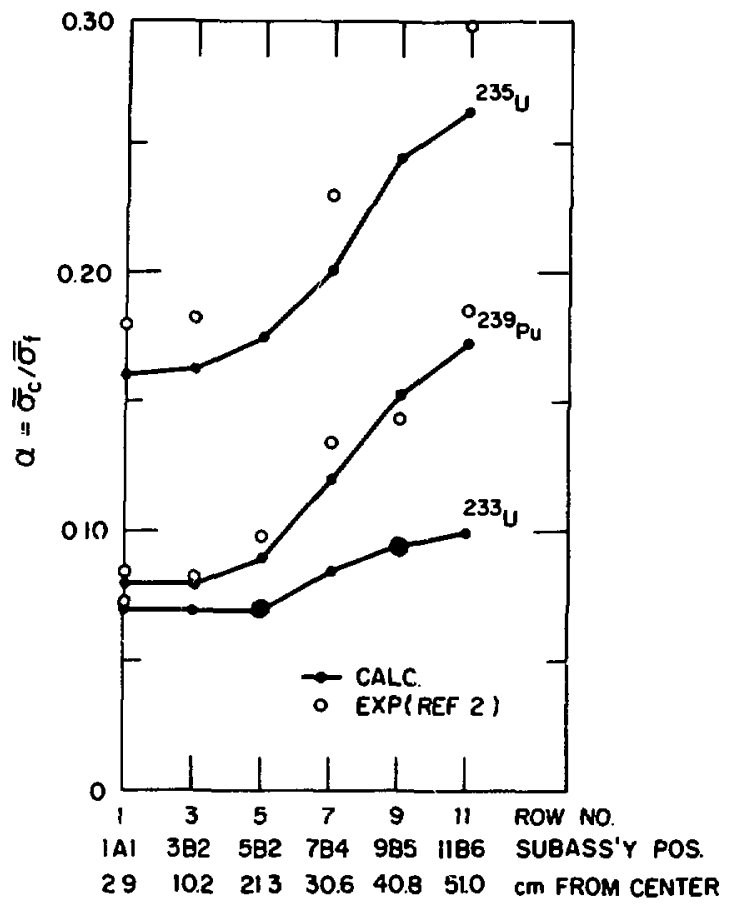

Fig. 7. Values of $\alpha$ for ${ }^{235} \mathrm{U},{ }^{239} \mathrm{Pu}$, and ${ }^{233} \mathrm{U}$ in Subassemblies at Various Radial Positions in EBR-II. ANL Neg. No. 104-294 Rev. 1.

\section{B. Radial Dependence of $\alpha$ Assuming RZ Geometry}

The radial dependence of $\alpha$ for the isotopes was also obtained from the two-dimensional, RZ-geometry calculation previously described. Values for positions deep into the radial blanket could be calculated in this manner. (The XY-geometry calculations a re not dimensionally extensive enough in the outer radial regions to be reliable for calculational interpretation of the foil experiments in rows 13 and 15.)

Figures 8, 9, and 10 compare the calculated and experimental values of $\alpha$ for the fertile isotopes ${ }^{240} \mathrm{Pu}$, ${ }^{242} \mathrm{Pu}$, and ${ }^{238} \mathrm{U}$, respectively, at the different radial distances from core center. Figures 11,12, and 13 make analogous comparisons for the fissile isotopes ${ }^{233} \mathrm{U},{ }^{235} \mathrm{U}$, and ${ }^{239} \mathrm{Pu}$, respectively. The experimental value for ${ }^{239} \mathrm{Pu}$ at the $71-\mathrm{cm}$ distance is consider ably greater than the calculated value.

\section{Axial Dependence of $\alpha$}

The axial variations of $\alpha$ were analyzed using the two-dimensional, RZ-geometry transport calculations previously described. Regions

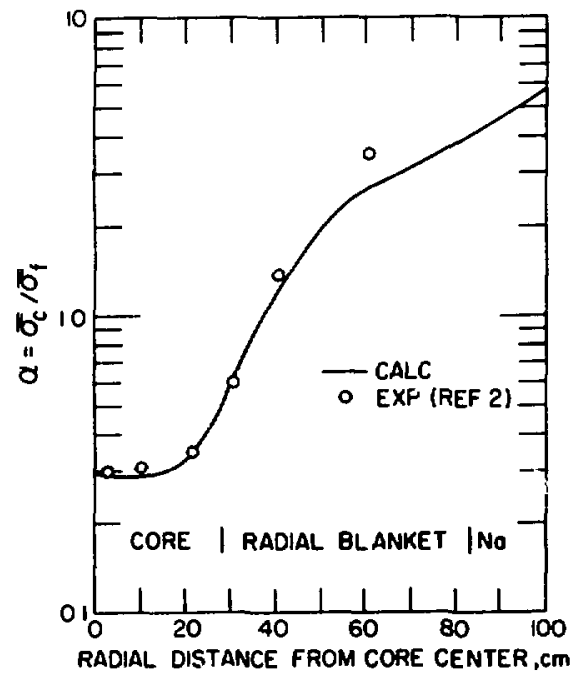

Fig. 8. Radial Profile of $\alpha$ for $240 \mathrm{Pu}$ in $\mathrm{EBR}-\mathrm{II}$

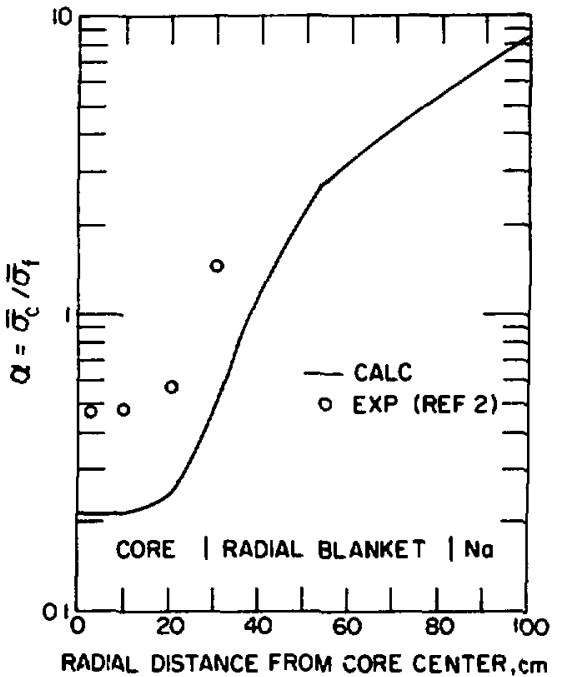

Fig. 9. Radial Profile of $\alpha$ for $242 \mathrm{Pu}$ in EBR-II 


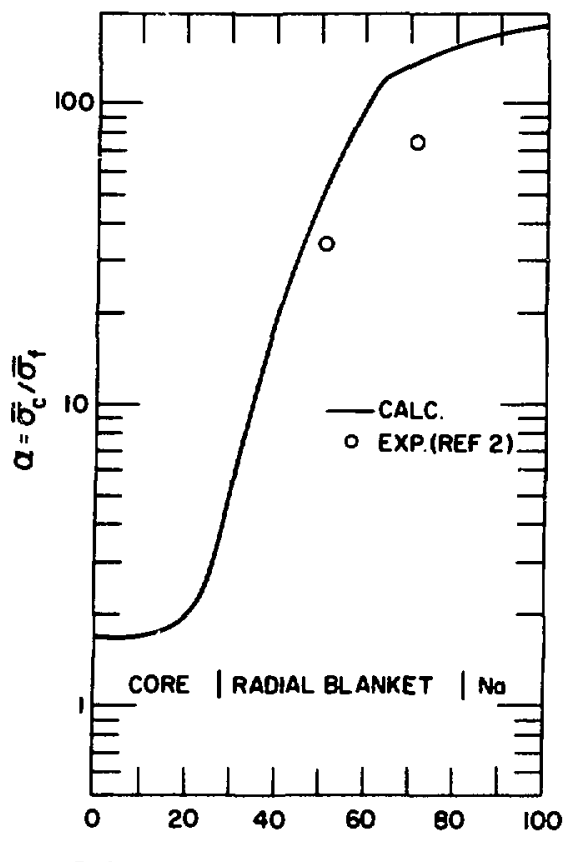

Fig. 10

Radial Profile of $\alpha$ for ${ }^{238} \mathrm{U}$ in EBR-II

Fig. 11

Radial Profile of $\alpha$ for ${ }^{233} \mathrm{U}$ in EBR-II
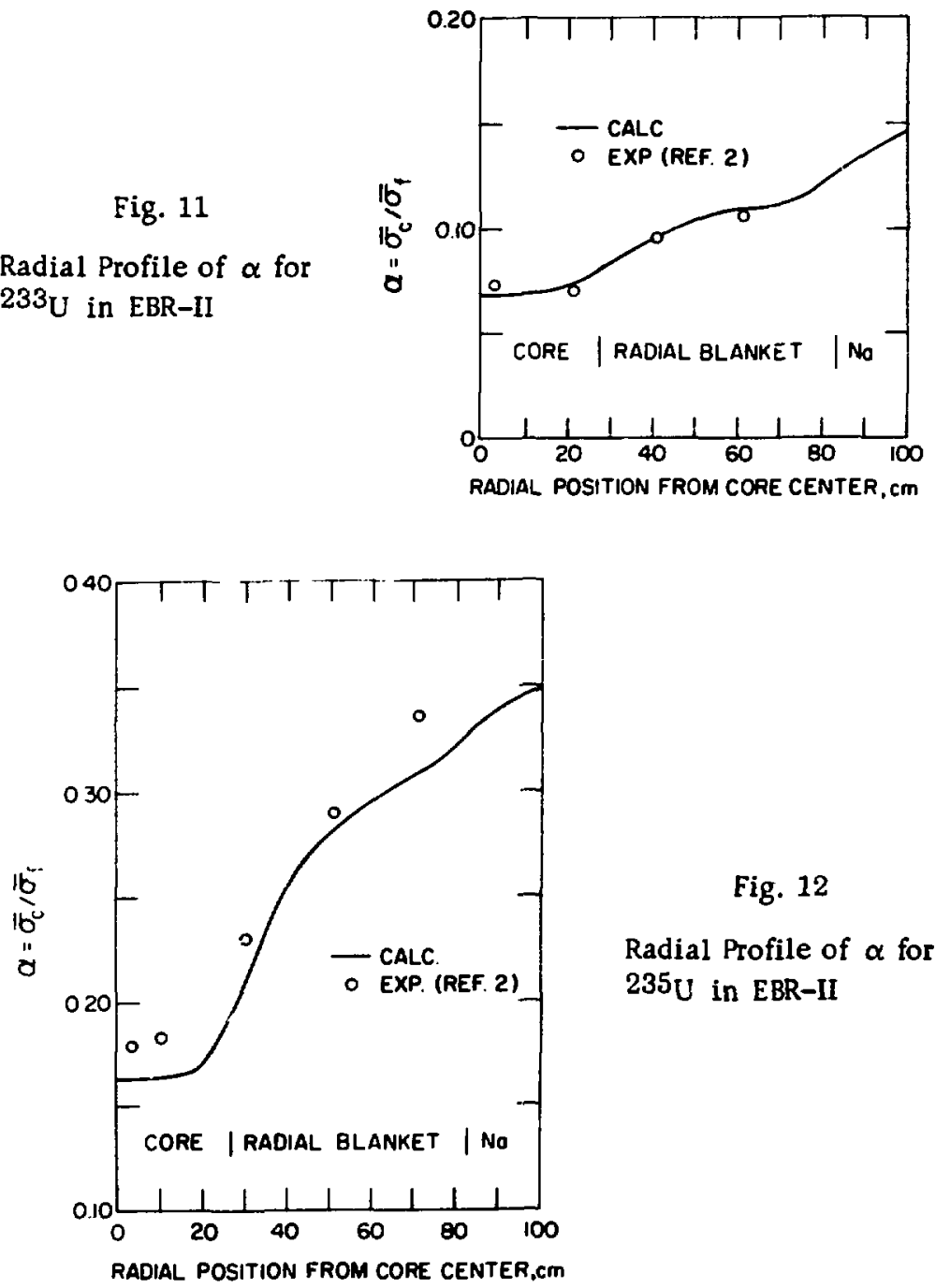

Fig. 12

Radial Profile of $\alpha$ for $235 \mathrm{U}$ in EBR-II 


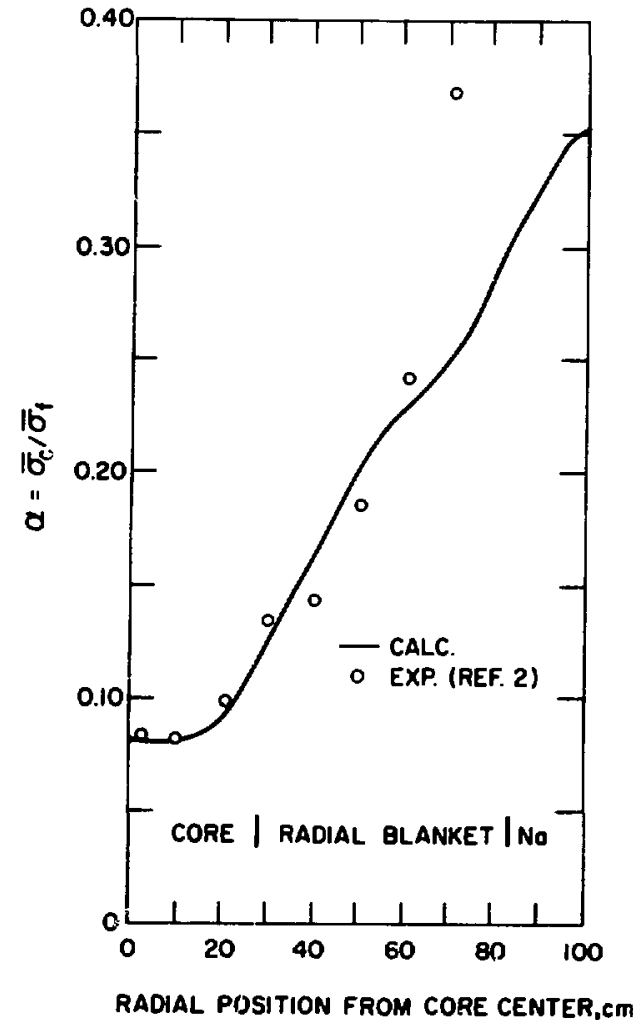

Fig. 13. Radial Profile of $\alpha$ for $239 \mathrm{Pu}$ in EBR-II representing pin tops, scdium gaps, the axial blanket, and top fixtures were detailed. The presence of the intervening regions of the pin tops and sodium gaps between the core and the axial blanket causes a very rapid increase of $\alpha$ with axial position through these regions. Errors in cross sections for the materials of these regions, therefore, can lead to very large errors in calculated $\alpha$ values. In addition, the determination of the effective atomic densities for these intervening regions, which are structurally heterogeneous, may represent a possible problem.

Figure 14 compares the calculated and experimental values of $\alpha$ for the fertile isotope ${ }^{240} \mathrm{Pu}$. The calculated values compare well with the experimental values, three of which are for positions in the axial blanket.

Figure 15 compares the calculated and experimental values for ${ }^{242} \mathrm{Pu}$. The

magnitudes differ considerably, but the shape of the curve of calculated values is similar to a curve fit to the experimental points.

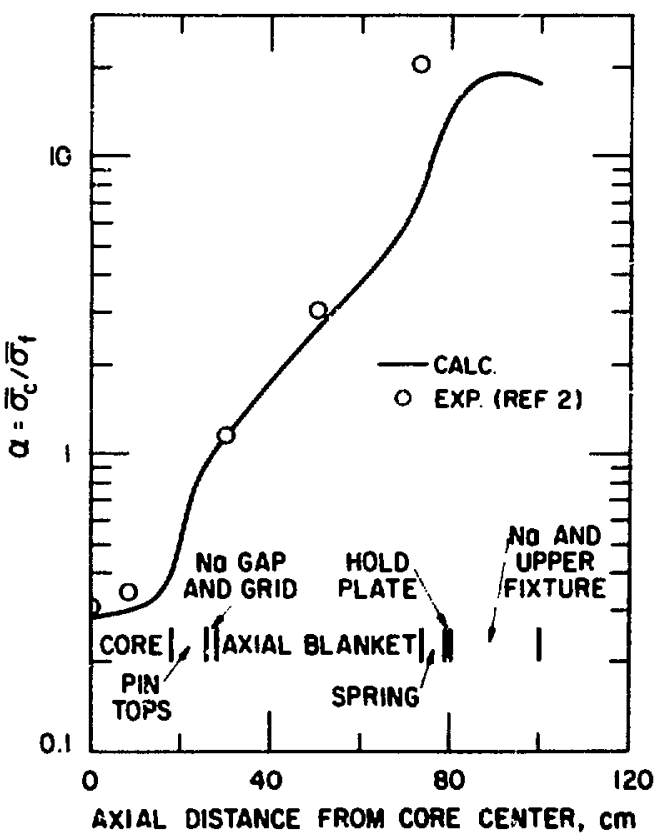

Fig. 14. Axial Profile of $\alpha$ for 240 Pu in EBR-II. ANL Neg. No. 104-297 Rev. 1.

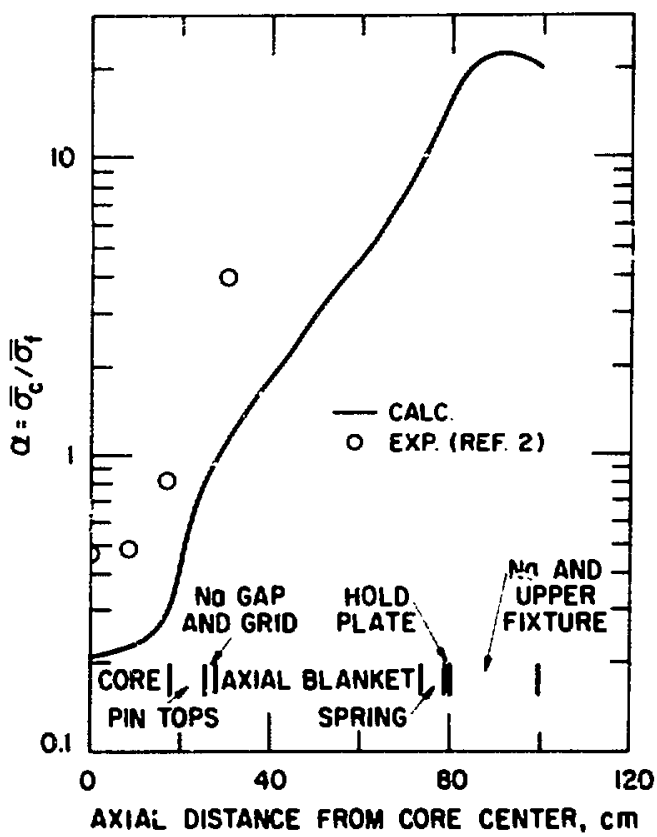

Fig. 15. Axial Profile of $\alpha$ for ${ }^{242} \mathrm{Pu}$ in EBR-II. ANL Neg. No. 104--292 Rev. 1. 


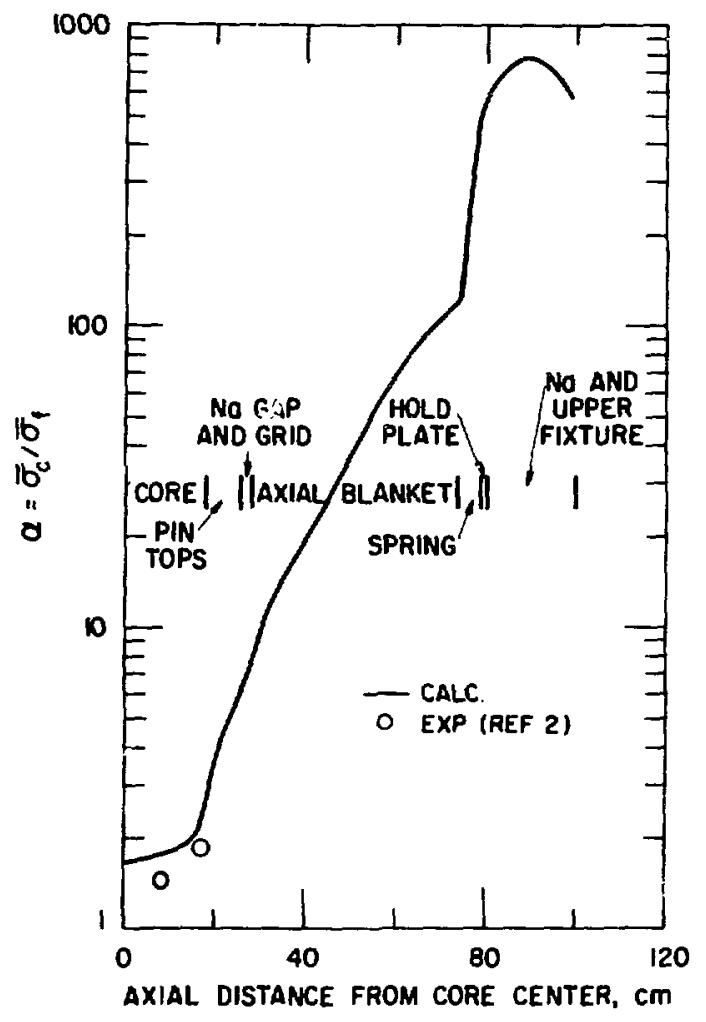

Fig. 16. Axial Profile of $\alpha$ for $238 \mathrm{U}$ in EBR-II. ANL Neg. No. 104-291 Rev. 1.
Figures 16 and 17 show the calculated and experimental values for ${ }^{238} \mathrm{U}$ and ${ }^{233} \mathrm{U}$, respectively.

Figure 18 shows the axial dependence of ${ }^{235} \mathrm{U}$. It was previously noted (in Sec. V.A above) that in a radial direction the calculated values of $\alpha$ for this isotope were consistently smaller than the experimental values. In an axial direction, this is also the case in the core region.

Figure 19 shows the values of $\alpha$ for ${ }^{239} \mathrm{Pu}$. (Two values are shown at about $8 \mathrm{~cm}$; one is for $-8 \mathrm{~cm}$ and the other for $+8 \mathrm{~cm}$.) The calculated values appear to agree with the experimental values reasonably well through the gap.

D. Central Capture and Fission Ratios

Table IX lists the capture and fission ratios, relative to ${ }^{233} \mathrm{U}$, for ${ }^{235} \mathrm{U}$, ${ }^{238} \mathrm{U},{ }^{239} \mathrm{Pu},{ }^{240} \mathrm{Pu}$, anc ${ }^{242} \mathrm{Pu}$ at the core

center. (These ratios are listed relative to ${ }^{233} \mathrm{U}$, instead of ${ }^{235} \mathrm{U}$, because consistent deviations were noted for ${ }^{235} \mathrm{U}$.) The table also shows the ratios of the calculated ratios to the reported experimental ratios.

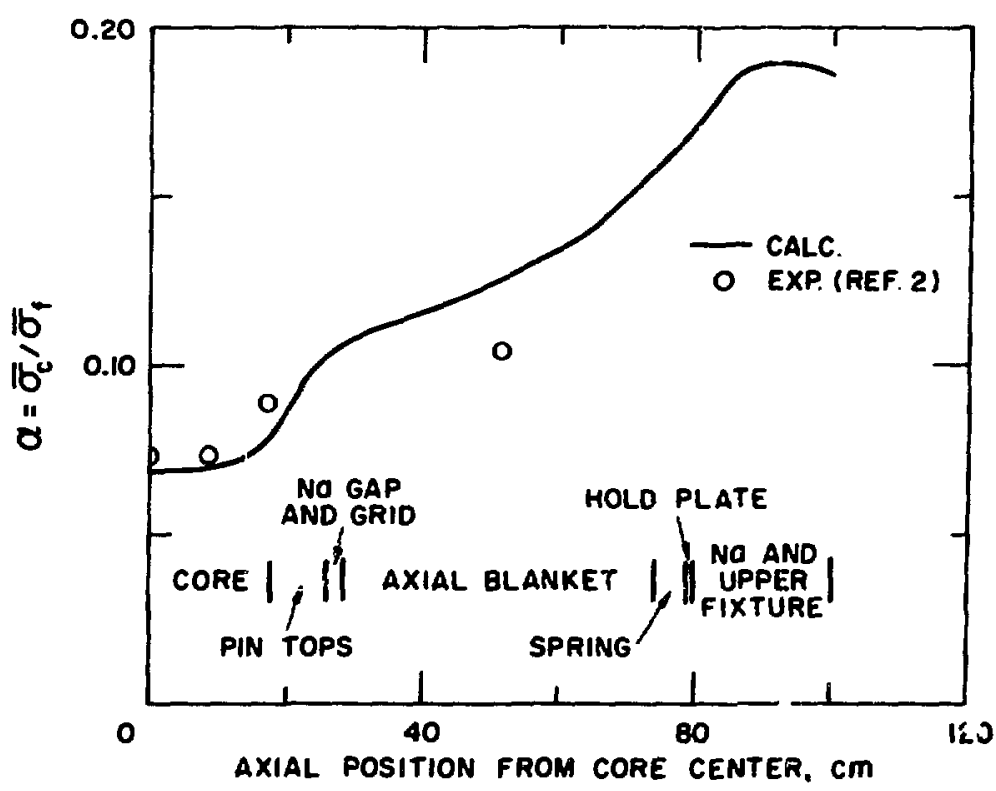

Fig. 17. Axial Profile of $\alpha$ for ${ }^{233} \mathrm{U}$ in EBR-II. ANL Neg. No. 104-293 Rev. 2. 


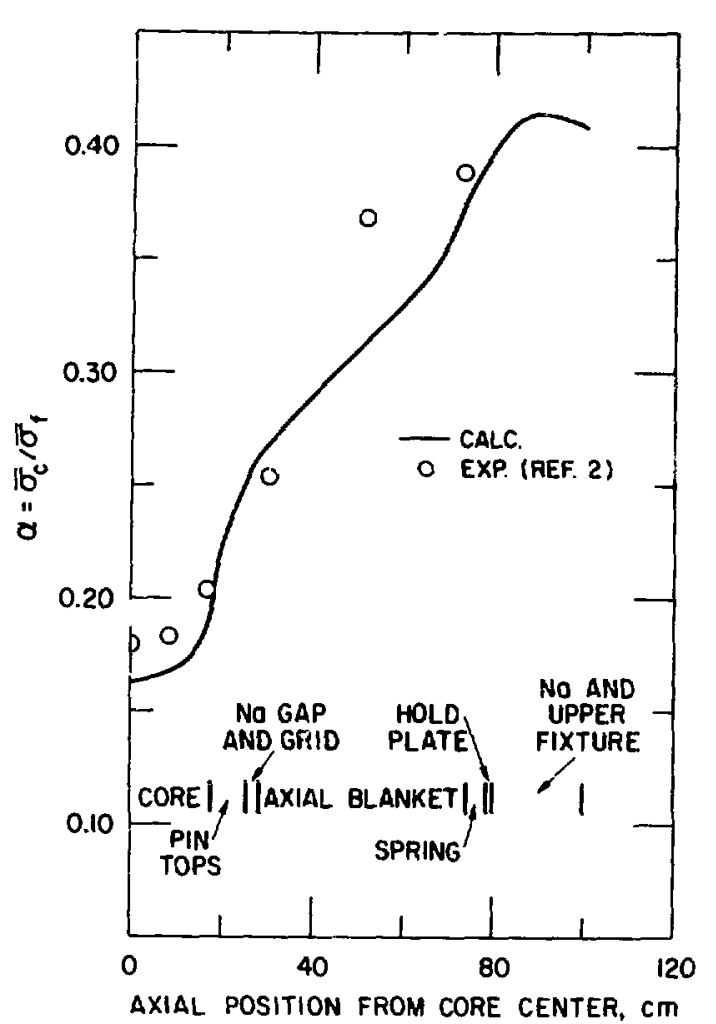

Fig. 18. Axial Profile of $\alpha$ for ${ }^{235} \mathrm{U}$ in EBR-lI. ANL Neg. No. 104-298 Rev. 2.

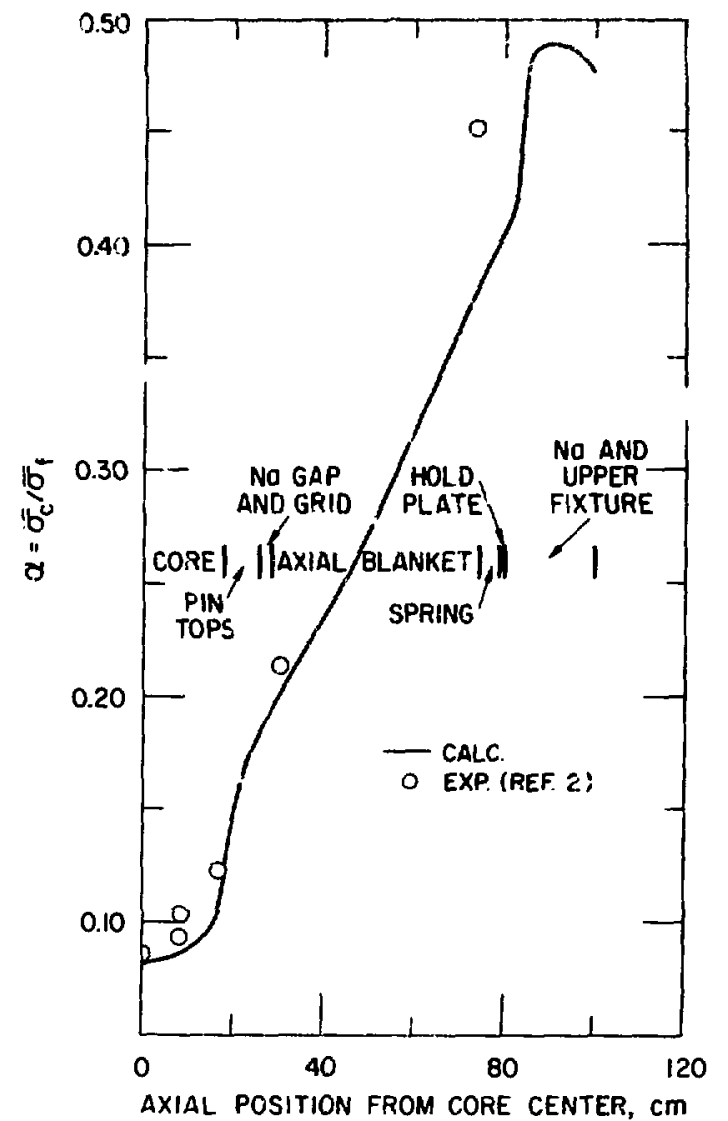

Fig. 19. Axial Profile of $\alpha$ for ${ }^{239_{\mathrm{Pu}}}$ in EBR-II. ANL Neg. No. 104-299 Rev. 2.

TABLE IX. Central Capture and Fission Ratios in EBR-II Core

\begin{tabular}{|c|c|c|c|c|c|c|}
\hline \multirow[b]{2}{*}{ Ratio } & \multicolumn{3}{|c|}{ Capture Ratio } & \multicolumn{3}{|c|}{ Fission Ratio } \\
\hline & Calc & $\operatorname{Exp}^{a}$ & Calc/Exp & Calc & $\operatorname{Exp}^{a}$ & $\mathrm{Calc} / \operatorname{Ex}_{\mathrm{p}}$ \\
\hline${ }^{235} \mathrm{U} /{ }^{233} \mathrm{U}$ & 1.53 & 1.66 & 0.92 & 0.66 & 0.67 & 0.99 \\
\hline${ }^{238} \mathrm{U} /{ }^{233} \mathrm{U}$ & 1.06 & 0.93 & 1.14 & 0.042 & 0.047 & 0.89 \\
\hline${ }^{239} \mathrm{Pu} /{ }^{233} \mathrm{U}$ & 0.92 & $\mathrm{~b}$ & $\mathrm{~b}$ & 0.78 & $\mathbf{b}$ & b \\
\hline${ }^{240} \mathrm{Pu} /{ }^{233} \mathrm{U}$ & 1.26 & 1.39 & 0.91 & 0.32 & 0.33 & 0.97 \\
\hline${ }^{242} \mathrm{Pu} /{ }^{233} \mathrm{U}$ & 0.79 & 0.73 & 1.08 & 0.27 & $0.11(?)$ & $2.5(?)$ \\
\hline
\end{tabular}

afr rom Ref. 2.

bNormalized values for experimental capture rate and fission rate for ${ }^{239} \mathrm{Pu}$ are not available. 
The calculated capture ratios differ by about $\pm 10 \%$ from the experimental ratios. Except for the value for ${ }^{242} \mathrm{Pu}_{\mathrm{f}} /{ }^{233} \mathrm{U}_{\mathrm{f}}$, the fission ratios differ by about the same amount from the experimental catios. The calc/ exp ratio for ${ }^{242} \mathrm{Pu}_{\mathrm{f}} /{ }^{233} \mathrm{U}_{\mathrm{f}}$ is $\sim 2.5$. This suggests that the large discrepancy between the calculated and the reported foil-measured $\alpha$ for ${ }^{242} \mathrm{Pu}$ is most likely due to a discrepancy between calculated and reported foil-measured fission rates. The difference between the ENDF/B-based muitigroup fission cross sections used in this study and the measured differential cross sections reported in the literature ${ }^{5,6}$ is not large enough to account for this discrepancy. Therefore, the discrepancy may be due to a systematic error in the foil fission measurements.

\section{ACKNOWLEDGMENTS}

We acknowledge the many helpful discussions with $M . D$. Dudey and R. R. Heinrich of the Chemical Engineering Division concerning the test data. We also acknowledge the help of F. S. Kirn in many questions regarding EBR-II loadings.

\section{REFERENCES}

1. J. C. Case, Core-loading Diagrams for EBR-II Puns 4 through 38 (April 1965 through mid-December 1969), ANL/EBR-007 (Dec 1969).

2. R. R. Heinrich, J. Williams, A. A. Madson, and N. D. Dudey, Integral Measurements in EBR-II of Capture Rates, Fission Rates, and Alpha for ${ }^{235} \mathrm{U},{ }^{235} \mathrm{U},{ }^{238} \mathrm{U},{ }^{239} \mathrm{Pu},{ }^{240} \mathrm{Pu}$, and ${ }^{242} \mathrm{Pu}, \mathrm{ANL}-7791$ (July 1971).

3. F. R. Mynatt, DOT, A Two-dimensional Discrete-ordinates Transport Code, K-1694, Radiation Shielding Information Center, ORNL.

4. B. J. Toppe1, A. I. Rago, and D. M. O'Shea, $\mathrm{MC}^{2}$, A Code to Caiculate Multigroup Cross Sections, ANL-7318 (June 1967).

5. J. R. Stiehn et al., Neutron Cross Sections, Volume III, BNL 325.

Suppl. No. 2, Second Edition (Feb 1965).

6. P. A. Seeger, Fission Cross Sections from Pommard, LA-4420, LASL (June 1970). 